\title{
Managing an essential public health menace - Osteoarthritis of knee, through janu basti procedure of traditional Indian medicine - A pilot study
}

Alka Mishra $^{1, *}$ and Vandana Shrivastava ${ }^{1}$

${ }^{1}$ Department of Ayurveda and Holistic Health, Dev Sanskriti Vishwavidyalaya, Gayatrikunj-Shantikunj, Haridwar-249411, Uttarakhand, India

\begin{abstract}
Background: Osteoarthritis $(\mathrm{OA})$ of knee is an essential public health menace, and a major cause of mobility impairment, mainly among the elderly population. Side-effect free, long-term management of this disease is still not achieved.
\end{abstract}

Methods: This pilot study explores the efficacy of Janu Basti, which is a simple and effective, oleation and sudation procedure of Ayurveda, in the management of this disease. Janu Basti was administered with Ksheerbala oil, followed by local application of medicated steam; total time of therapy was 40-50 minutes per day, and this continued for 21 days. Then there was 5 weeks follow-up, during which the patients had to massage the affected knee daily with Ksheerbala oil, followed by hot fomentation, on their own, at home. Subjective parameters (pain, swelling, stiffness, and crepitus) and objective parameters (WOMAC score, ROM, Walking Time) were analyzed during the study.

Results: Six patients completed the study, including treatment of nine knees. Significant improvement was observed in the median values of subjective parameters (pain, swelling, stiffness, and crepitus) and objective parameters (WOMAC score, ROM, Walking Time) analyzed during the study. Patients experienced increasing relief with time, both during initial therapeutic intervention, and follow-up involving self-management at home.

Conclusions: The traditional Indian medicine based therapeutic procedure has shown significant promise in the management of $\mathrm{OA}$ of knee, both during therapeutic intervention, and follow-up involving self-management at home.

Keywords: Ayurveda; herbal medicine; Janu Basti; Ksheerbala oil; osteoarthritis of knee; traditional medicine

\begin{abstract}
*Corresponding author: Alka Mishra, Department of Ayurveda and Holistic Health, Dev Sanskriti Vishwavidyalaya, GayatrikunjShantikunj, Haridwar-249411, Uttarakhand, India. Email: alka. mishra@dsvv.ac.in

Received 8 June 2020; Revised 19 August 2020; Accepted 27 August 2020; Published 3 September 2020
\end{abstract}

Citation: Mishra A, Shrivastava V. Managing an essential public health menace - Osteoarthritis of knee, through janu basti procedure of traditional Indian medicine - A pilot study. J Med Sci Res. 2020; 8(4):150-159. DOI: http://dx.doi.org/10.17727/ JMSR.2020/8-20

Copyright: (C) 2020 Mishra A et al. Published by KIMS Foundation and Research Center. This is an open-access article distributed under the terms of the Creative Commons Attribution License, which permits unrestricted use, distribution, and reproduction in any medium, provided the original author and source are credited. 


\section{Introduction}

Osteoarthritis (OA) of knee is an essential public health menace, and a major cause of mobility impairment mainly among the elderly population [1-3]. Its symptoms include joint pain, joint stiffness, instability and loss of function, which severely affect day to day activities [3]. Therapeutic interventions conventionally employed for OA include the use of physiotherapy, weight control, different types of analgesics, intra-articular steroid injections, knee replacement surgery, etc.[1, 2]. However, side-effect free, long-term management of this disease is still not achieved [1-3]; hence, there is a definite need to look for other safe and effective therapies for patients suffering from $\mathrm{OA}$ of knee.

According to Ayurveda, the traditional Indian system of medicine, the disease that closely resembles the symptoms of OA of knee is Janu Sandhigata Vata [1, 3-5]. In this system of medicine, oleation and sudation therapies are recommended, as well as commonly used for the management of this disease with encouraging results [1,3-5]. Janu Basti is a simple and effective oleation and sudation procedure of Ayurveda, which involves retaining warm medicated oil over the knee joint for sufficiently long duration [6]; the oleaginous properties of the oil, combined with its medicinal properties, as well as the sudation induced by the warm oil, can produce the desired therapeutic effect. Although it is a widely used practice in India, and research studies are available [7-9] that explore its efficacy while using different kinds of medicinal oils, yet quantitative exploration of the effectiveness of Janu Basti with Ksheerbala oil in the management of $\mathrm{OA}$ of knee is not readily available in the peer reviewed open literature. The present study is a preliminary attempt to address this important need, so that the people suffering from this disabling disorder can be motivated to benefit from this simple procedure.

\section{Methodology}

The objective of this study was to evaluate the efficacy of Janu Basti procedure in the management of Osteoarthritis (OA) of knee.

\subsection{Study design}

Experimental, pilot study, with pre-test - post-test research design was adopted.

\subsection{Description of variables}

The Independent Variable of this study is Janu Basti, which is described below in Section 2.6, i.e. Intervention.

\section{The dependent variables of this study are as follows:}

\subsubsection{Subjective parameters}

These include joint pain, joint swelling, joint stiffness, crepitus, which were analyzed through pre-defined assessment criteria and grading.

\subsubsection{WOMAC index (Modified - CRD Pune Version)}

The Western Ontario and McMaster Universities (WOMAC) osteoarthritis (OA) index was developed to assess pain, stiffness, and physical function in patients of knee and / or hip OA $[10,11]$. The WOMAC consists of 24 items, rated on a five point Likert scale, and divided into 3 sub-scales $[10,11]$ : Pain (5 items), stiffness (2 items), and physical function (17 items).

The WOMAC index (Modified - CRD Pune Version), suitable for Indian-Asian use, has been validated against Western Ontario and McMaster Universities (WOMAC) OA index; It primarily consists of WOMAC scale for pain, WOMAC scale for stiffness, and a modified WOMAC function scale, to suit Indian conditions and activities [10,12]. This scale is successfully used in many researches for the assessment of OA of knee [10,12]. WOMAC Index (Modified - CRD Pune Version) has been used in this study for the assessment of OA of knee.

\subsubsection{Range of motion (ROM) - by goniometer}

Range of motion (ROM) of the knee joint was measured by a goniometer (in degrees) to assess the amount of movement of the knee joint.

\subsubsection{Walking time}

Walking time was assessed by asking the patient to walk a particular distance, and noting the time taken (in seconds) for the same.

\subsection{Selection of patients}

This study was conducted to be an open trial, with single group pilot study. Patients were selected through purposive sampling from the Out Patient Section of the Department of Ayurveda and Holistic Health, Dev Sanskriti Vishwavidyalaya, Haridwar, 
between September 2017 to December 2017. Screening of 17 patients was done, out of which 7 patients fulfilled the inclusion criteria and joined the study; one patient left in between, so total six patients completed the study.

All the patients went through routine hematological examination (Hemoglobin, TLC, DLC, ESR), biological investigations like serum calcium, serum uric acid, serum cholesterol, fasting blood sugar and urine analysis - routine and microscopic - to exclude any other pathology. The diagnosis was confirmed by $\mathrm{X}$-ray examination of involved joint.

The study was approved by the 'Research Ethics Committee (REC) for Research involving Human Participants' of Dev Sanskriti Vishwavidyalaya, Haridwar (REC-DSVV) (REC Ref no.: DSVV/PhD/ OS(AY)/0130108472, Dated: 11 May 2016). Informed consent was obtained from all the patients before the start of the therapy.

\subsection{Inclusion criteria}

- Age - 40 to 70 years irrespective of gender, religion and socio-economic status

- Subjects having clinical features of OA of knee

- Subjects fit to undergo Janu Basti, and who were willing to sign the Informed Consent

\subsection{Exclusion criteria}

- $\quad$ Subjects suffering from any other type of arthritis like rheumatoid arthritis, psoriatic arthritis, infective arthritis, gout, ankylosing spondylitis

- Subjects with any other serious systemic disorder, which may interfere with the treatment

- Traumatic causes like fracture

- Pregnancy and Lactation

\subsection{Intervention}

A total of six patients suffering from $\mathrm{OA}$ of knee were administered the treatment. The treatment involved administration of Janu Basti on the affected knee joint for 35 to 40 minutes, followed by local application of medicated steam (Nadi Sweda) for 5 to 10 minutes.

\subsubsection{Janu Basti}

In Janu Basti, warm medicated oil (Ksheerbala oil) was retained over the anterior portion of the painful knee joint (at supine position) for 35 to 40 minutes. In order to retain the oil, a leak-proof frame was made around the patellar surface of the knee, with the dough of split black gram (without skin) powder (250gm) [6]. Warm oil (that was warmed in a hot water bath) was filled in this cup; the top level of oil was kept about 1 inch above the skin surface [6]. It was made sure that the temperature of oil was bearable for the patient. In order to maintain the warmth of the oil, small amount of cooled oil was periodically removed with a piece of cotton, was warmed, and again filled back.

The medicated oil used in the present study was Ksheerbala oil $(250 \mathrm{ml}$ to $300 \mathrm{ml}$, for each knee, for three days), whose ingredients include Sida cordifolia Linn. (Bala), cow's milk (Ksheera), with Sesame oil as base. The medicinal properties of this oil are useful in the management of degenerative diseases of various joints of the body $[6,13]$.

\subsubsection{Local application of medicated steam (Nadi Sweda)}

Janu Basti was followed by local application of medicated steam (Nadi Sweda) [6] on the affected knee joint for 5 to 10 minutes. The Nadi Sweda instrument consists of an electric pressure cooker, with a rubber pipe (about 5 feet long) attached to its nozzle, through which the steam flows out [6]. While administering the medicated steam, the tip of the pipe is to be kept at a distance of about 1.5 to 2 feet from the target region (affected knee joint in present case), and rotated continuously so that the steam does not cause burning. A bundle of 500 gm medicinal herbs (Dashamoola was used in the present study) and water were kept in the pressure cooker to generate medicated steam [6]. Dashamoola is a mixture of ten medicinal herbs, i.e. Desmodium gangeticum, Uraria picta, Solanum indicum, Solanum xanthocarpum, Tribulus terrestris, Aegle marmelos, Clerodendrum phlomidis, Gmelina arborea, Oroxylum indicum, Stereospermum suaveolens. The medicinal properties of Dashamoola are useful in the management of degenerative diseases of various joints of the body $[14,15]$.

\subsubsection{Details of administered therapeutic procedure}

Pre-procedure: After releasing natural urges (urine and stool), patient was made to lie down on massage table in supine position, and expose the knee area properly. 
Main-procedure: The dough of split black gram (without skin) powder was prepared with sufficient quantity of water. This dough was stuck over the affected knee joint to form a frame of two inches height and five inches diameter. After making sure that there is no leakage from the walls of the frame, it was gradually filled with Ksheerbala oil with the help of a small piece of cotton of one inch thickness. The oil was made to stay there, while maintaining constancy of its temperature; for this, small amount of oil was taken out after every 5 to 7 minutes, warmed, and mixed with the remaining oil in the frame.

Post-procedure: After completing the therapy, the entire oil was taken out from the frame with the help of cotton piece, collected in a separate vessel for using over the next two days of therapy. The frame of black gram was also removed. Next, light massage of the affected joint was done for five minutes. After that medicated steam (generated from the decoction of Dashamoola) was applied on the affected knee joint for 5 to 10 minutes.

So, the total time duration of therapy was 40 to 50 minutes per day, and this intervention was given for 21 days; after that there was a follow-up time period of 5 weeks. During follow-up time period, patient had to daily do massage of the affected knee with Ksheerbala oil, followed by plain water hot fomentation, on their own, at home.

\subsection{Precautions}

Patient was advised to avoid exposure to cold air or wind, immediately after taking the therapy. During the course of treatment, patient was advised to take proper rest, avoid too much walking and climbing the stairs, lifting heavy objects, too much physical and mental exertion, traveling, remaining awake late in the night, suppression of urges, etc. (Bhaishajya Ratnavali, Vatavyadhi Chikitsa 26/ 626 - 630) [16], (Yoga Ratnakara, Purvardha,Vatavyadhi) [17].

\subsection{Dietary and other recommendations}

Patient was advised to take warm, fresh and easily digestible food items; especially green vegetables, green gram pulse, porridge, boiled sprouts, overnight soaked dry fruits, fenugreek, seasonal fruits, lukewarm water to drink, for taking bath, etc. (Bhaishajya Ratnavali, Vatavyadhi Chikitsa 26/ 611 - 625) [16], (Yoga Ratnakara, Purvardha,Vatavyadhi)
[17]. Also, patient was advised to avoid heavy to digest food items like black gram pulse, beans, cauliflower, peas, okra, pumpkin, potato, polished rice, as well as cold, sour, oily, spicy food items, etc. (Bhaishajya Ratnavali, Vatavyadhi Chikitsa 26/ 626 630) [16], (Yoga Ratnakara, Purvardha,Vatavyadhi) [17].

During the study period, the patients had been advised to only follow the present intervention and recommendations, and not take any other medication/ intervention.

\subsection{Assessment criteria and grading}

To assess the effect of therapy, the criteria given below were followed. Grading was assigned to the criteria depending on their severity. Since range of motion (ROM) and walking time are quantitative data, hence their actual values were used, and numerical grade was not assigned to these.

From the time the therapy was started, required objective tests and assessments were done on day 0 (i.e. before starting the therapy), on the $11^{\text {th }}$ day of the therapy, after 3 weeks (i.e. upon completion of the therapy), after 5 weeks (from the starting date of the therapy), and after 8 weeks (from the starting date of the therapy). After the $8^{\text {th }}$ week, X-ray of involved knee joint/s was done once again.

\subsubsection{Assessment criteria and grading of subjective} parameters

Joint pain

$$
\begin{aligned}
& \text { - No Complaint - } 0 \\
& \text { - Tells on enquiry - } 1 \\
& \text { - Complains frequently - } 2 \\
& \text { - } \quad \text { Excruciating condition - } 3
\end{aligned}
$$

Joint swelling

- $\quad$ No swelling - 0

- Slightly obvious - 1

- $\quad$ Covers well over the bony prominence -2

- $\quad$ Marked and much elevated - 3

$$
\begin{aligned}
& \text { Joint stiffness } \\
& \text { - } \text { No Stiffness - } 0 \\
& \text { - }<30 \text { minutes }-1 \\
& \text { - } \geq 30 \text { minutes }-2
\end{aligned}
$$


Crepitus

- $\quad$ No crepitus - 0

- Occasional crepitus - 1

- $\quad$ Persistent and palpable crepitus - 2

- $\quad$ Persistent and audible crepitus - 3

2.9.2 Assessment criteria and grading of objective parameters

WOMAC (for individual question)

- $\quad$ None - 0

- $\quad$ Slight - 1

- $\quad$ Moderate - 2

- $\quad$ Very - 3

- $\quad$ Extreme - 4

Range of motion (ROM)

- $\quad$ Normal Flexion $135^{\circ}$ - None

- $\quad<135^{\circ}$ and $\geq 100^{\circ}$ - Mild

- $\quad<100^{\circ}$ and $\geq 75^{\circ}$ - Moderate

- $\quad<75^{\circ}$ - Severe

Walking time to cover $21 \mathrm{~m}$ distance

- Up to $20 \mathrm{~s}$ - None

- 21 s to $30 \mathrm{~s}$ - Mild

- 31 s to $40 \mathrm{~s}$ - Moderate

- 41 s to $50 \mathrm{~s}$ - Very

- $\quad 51$ s to $60 \mathrm{~s}$ - Extreme

$X$-ray finding (Kellgren-Lawrence radiographic grading scale of $O A$ of tibia femoral joint):

(However, any significant radiographical changes were not expected after the completion of the study)

- $\quad$ No radiographic findings of OA - 0

- Minute osteophytes of doubtful clinical significance - 1

- Definite osteophytes with unimpaired joint space - 2

- Definite osteophytes with moderate joint space narrowing - 3

- Definite osteophytes with severe joint space narrowing and subchondral sclerosis - 4

\subsection{Statistical analysis}

For statistical analysis, non-parametric Wilcoxon signed-rank test was applied. A value of $\mathrm{p}<0.05$ was considered statistically significant.

\section{Results}

Six patients completed the study. Data collected from the patients at the beginning of the study is as follows:

- $\quad$ Gender - 3 (50\%) male and 3 (50\%) female

- $\quad$ Age group - 3 (50\%) belonged to 61-70 years age group ; 2 (33\%) belonged to $51-60$ years age group ; 1 (17\%) belonged to $40-50$ years age group

- $\quad$ Education - 3 (50\%) were postgraduate ; 2 (33\%) were graduate

- $\quad$ Socio-economic status - 3 (50\%) middle class ; 2 (33\%) upper middle class

- $\quad$ Nature of work - 4 (66.67\%) did walking / standing type of work

- $\quad$ Type of job - 3 (50\%) belonged to service class ; 2 (33\%) were house-wife ; 1 (17\%) was businessman

- $\quad$ Diet - All the patients were vegetarian

The background characteristics given in Table 1 were calculated using $n=9$, i.e. total number of affected knees that were treated in the present study (the justification for the same is given below in Section 3.1).

\subsection{Overall effect on the assessment criteria}

Table 2 lists the overall effect of the therapy on all the assessment criteria of this pilot study, except walking time; for all these parameters, $n=9$, i.e. the number of affected knees that were treated in this pilot study. For half of the patients, both the knees were affected, while only one knee was affected for the other half. Since, for the patients whose both the knees were affected, it was possible that a particular patient experienced different level of therapeutic effect in different knees, hence the parameters given in Table 2 were measured separately for both the knees, and as a result $\mathrm{n}=9$ for these parameters, i.e. the total number of knees treated in this study.

Table 3 lists the overall effect of the therapy on Walking Time; for this parameter, $n=6$, i.e. the number of patients in this pilot study, because Walking Time depends on the combined effect of both the knees. 
Table 1: Background characteristics of the patients - these were calculated using $n=9$, i.e. total number of affected knees that were treated in the present study.

\begin{tabular}{|c|c|}
\hline Characteristic & Description \\
\hline $\begin{array}{l}\text { Bilateral / Unilateral involvement of } \\
\text { knee joint }\end{array}$ & $\begin{array}{l}\text { Bilateral was present in } 3(50 \%) \text { patients } \\
\text { Unilateral was present in } 3(50 \%) \text { patients, out of which } 2(33 \%) \text { had left knee } \\
\text { involvement and } 1(17 \%) \text { had right knee involvement }\end{array}$ \\
\hline Chronicity & $\begin{array}{l}\text { In } 5(55.56 \%) \text { knees chronicity of }>3 \text { years } \\
\text { In } 3(33.33 \%) \text { knees chronicity of } 2 \text { to } 3 \text { years } \\
\text { In } 1(11.11 \%) \text { knee chronicity of }<1 \text { year }\end{array}$ \\
\hline Onset of the disease & Gradual in all the cases \\
\hline Pain & $\begin{array}{l}\text { Present in all the cases } \\
\text { In } 5(55.56 \%) \text { knees, pain was pricking type } \\
\text { In } 4(44.44 \%) \text { knees, pain was dull aching type }\end{array}$ \\
\hline Radiation of pain & Absent in $8(88.89 \%)$ knees \\
\hline Swelling of affected joint & Present in 7 (77.78\%) knees \\
\hline Onset of swelling & $\begin{array}{l}\text { In } 6(66.67 \%) \text { knees it was gradual } \\
\text { In } 1(11.11 \%) \text { knee it was sudden }\end{array}$ \\
\hline Course of swelling & $\begin{array}{l}\text { Intermittent in } 6(66.67 \%) \text { knees } \\
\text { Continuous in } 1(11.11 \%) \text { knee }\end{array}$ \\
\hline Stiffness & $\begin{array}{l}\text { Present in all the cases } \\
\text { In } 6(66.67 \%) \text { knees it appeared after activity } \\
\text { In } 2(22.22 \%) \text { knees there was morning stiffness } \\
\text { In } 1(11.11 \%) \text { knee stiffness was present all the time }\end{array}$ \\
\hline Crepitus (cracking sound in the knee) & $\begin{array}{l}\text { Present in all the cases } \\
\text { In } 7(77.78 \%) \text { knees crepitus was persistent and palpable }\end{array}$ \\
\hline
\end{tabular}

Table 2: Overall effect on the assessment criteria for all the parameters except walking time ( $\mathrm{n}=9 \mathrm{knees})$.

\begin{tabular}{|c|c|c|c|c|}
\hline Subjective parameters & $\begin{array}{c}\text { Median }(I Q R) \\
\text { Before treatment }\end{array}$ & $\begin{array}{c}\text { Median }(I Q R) \\
\text { After treatment }\end{array}$ & $p$ & $\%$ Relief \\
\hline Joint pain & $2(0)$ & $1(1)$ & $<0.01$ & 50.00 \\
\hline Joint swelling & $2(0)$ & $0(0)$ & $<0.01$ & 100.00 \\
\hline Joint stiffness & $1(0)$ & $0(1)$ & $<0.05$ & 100.00 \\
\hline Crepitus & $2(0)$ & $1(0)$ & $<0.01$ & 50.00 \\
\hline \multicolumn{5}{|l|}{ Objective parameters } \\
\hline ROM (in degrees) & $95(15)$ & $115(15)$ & $<0.01$ & 21.05 \\
\hline Overall WOMAC score & $48(1)$ & $9(4)$ & $<0.01$ & 81.25 \\
\hline WOMAC (a) pain & $8(2)$ & $1(1)$ & $<0.01$ & 87.50 \\
\hline WOMAC (b) stiffness & $3(1)$ & $0(1)$ & $<0.01$ & 100.00 \\
\hline WOMAC (c) physical function & $37(2)$ & $7(3)$ & $<0.01$ & 81.08 \\
\hline
\end{tabular}

Footnote: Values are presented as median (Interquartile Range). For statistical analysis, non-parametric Wilcoxon signed-rank test was applied. A value of $p<0.05$ was considered statistically significant. \% Relief was calculated as the percentage change in median values from before treatment to after treatment. IQR - Interquartile range. After treatment - It implies the end of the study period, which included the initial therapeutic intervention, and the follow-up time of self-management of the disease at home. 
Table 3: Effect on the assessment criteria for walking time ( $\mathrm{n}=6$ patients).

\begin{tabular}{|lllll|}
\hline Objective parameter & $\begin{array}{l}\text { Median (IQR) } \\
\text { Before treatment }\end{array}$ & $\begin{array}{l}\text { Median (IQR) } \\
\text { After treatment }\end{array}$ & $p$ & \% Relief \\
\hline Walking time (in seconds) & $25.5(4.75)$ & $15.5(3.25)$ & $<0.05$ & 39.22 \\
\hline
\end{tabular}

Footnote: Values are presented as median (Interquartile range). For statistical analysis, non-parametric Wilcoxon signed-rank test was applied. A value of $p<0.05$ was considered statistically significant. \%Relief was calculated as the percentage chage in median values from before treatment to after treatment. IQR - Interquartile range. After Treatment - It implies the end of the study period, which included the initial therapeutic intervention, and the follow-up time of self-management of the disease at home.

In Tables 2 and 3, the values have been presented as median (interquartile range), and \%relief was calculated as the percentage change in median values from 'before treatment' to 'after treatment'. It can be seen from Table 2 that the median value of overall WOMAC score was 48 before treatment, which reduced to 9 after treatment, giving a \%relief of $81.25 \%$, which is statistically significant with $\mathrm{p}<0.01$. Median value of joint pain was 2 before treatment, which reduced to 1 after treatment, giving a \%relief of $50 \%$, which is statistically significant with $\mathrm{p}<0.01$. Median value of joint swelling was 2 before treatment, which reduced to 0 after treatment, giving a \%relief of $100 \%$, which is statistically significant with $\mathrm{p}<0.01$. Median value of joint stiffness was 1 before treatment, which reduced to 0 after treatment, giving a \%relief of $100 \%$, which is statistically significant with $\mathrm{p}<0.05$. Median value of crepitus was 2 before treatment, which reduced to 1 after treatment giving a \%relief of $50 \%$, which is statistically significant with $\mathrm{p}<0.01$. Median value of ROM was $95^{\circ}$ before treatment, which increased to $115^{\circ}$ after treatment, giving a \%betterment of $21.05 \%$, which is statistically significant with $\mathrm{p}<0.01$.

It can be seen from Table 3 that the median value of walking time was 25.5 seconds before treatment, which reduced to 15.5 seconds after treatment, giving a \%relief of $39.22 \%$, which is statistically significant with $\mathrm{p}<0.05$.

No apparent change was observed in the X-ray examination before and after the treatment.

\subsection{Variation in the median value of each parameter} with the duration of therapy

From the time the therapy was started, required objective tests and assessments were done on day 0 (i.e. before starting the therapy), on the $11^{\text {th }}$ day of the therapy, after 3 weeks (i.e. upon completion of the therapy), after 5 weeks (from the starting date of the therapy - follow-up 1), and after 8 weeks (from the starting date of the therapy - follow-up 2). After the $8^{\text {th }}$ week, X-ray of involved knee joint/s was done once again.

Table 4 lists the variation in the median values of all the subjective and objective parameters with the duration of treatment, i.e. on days 0 (before starting the therapy), 11, 21, 36, and 56. Figure 1 shows the variation in median values with the duration of treatment for walking time, the overall WOMAC score, as well as the scores for the different sections of the WOMAC index, i.e. pain, stiffness, and physical function. It can be seen from Table 4, and Figure 1 , that the median values of all the parameters reduced with time, indicating the continuous relief experienced by the patients during the therapy, as well as during the follow-up period.

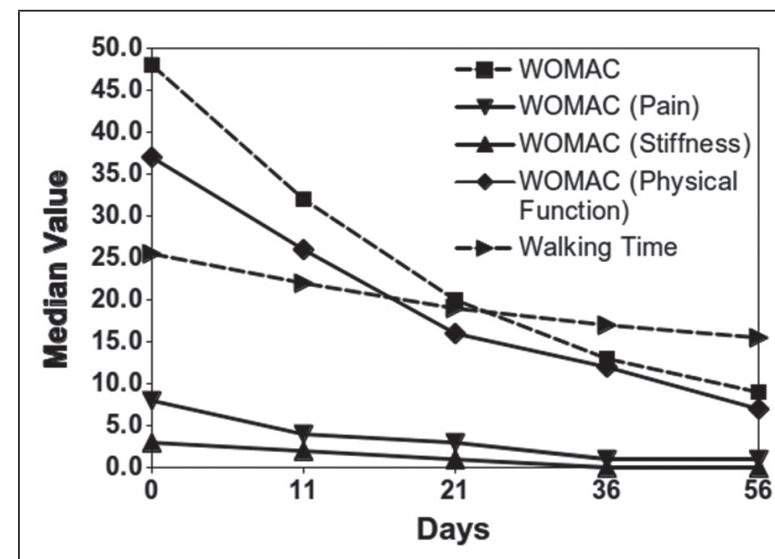

Figure 1: Variation in median values of WOMAC index scores, and walking time (in second), with the duration of treatment.

\section{Discussion}

The aim of this pilot study was to evaluate the efficacy of Janu Basti procedure with Ksheerbala oil in the management of osteoarthritis (OA) of knee. 
Table 4: Variation in the median values of all the subjective and objective parameters with the duration of treatment.

\begin{tabular}{|lllllllllll|}
\hline Days & Pain & Swelling & Stiffness & Crepitus & $\begin{array}{l}\text { ROM } \\
\text { (in degree) }\end{array}$ & WOMAC & $\begin{array}{l}\text { WOMAC } \\
\text { (Pain) }\end{array}$ & $\begin{array}{l}\text { W O M A C } \\
\text { (Stiffness) }\end{array}$ & $\begin{array}{l}\text { WOMAC } \\
\text { (Physical } \\
\text { function) }\end{array}$ & $\begin{array}{l}\text { Walking time } \\
\text { (in second) }\end{array}$ \\
\hline 0 & $2(0)$ & $2(0)$ & $1(0)$ & $2(0)$ & $95(15)$ & $48(1)$ & $8(2)$ & $3(1)$ & $37(2)$ & $25.5(4.75)$ \\
11 & $1(1)$ & $1(0)$ & $1(0)$ & $2(0)$ & $110(25)$ & $32(18)$ & $4(5)$ & $2(1)$ & $26(11)$ & $22(6)$ \\
21 & $1(0)$ & $0(1)$ & $1(0)$ & $2(1)$ & $113(11)$ & $20(2)$ & $3(3)$ & $1(0)$ & $16(3)$ & $19(3.5)$ \\
36 & $1(0)$ & $0(1)$ & $0(1)$ & $2(1)$ & $115(10)$ & $13(7)$ & $1(2)$ & $0(0)$ & $12(7)$ & $17(3.5)$ \\
56 & $1(1)$ & $0(0)$ & $0(1)$ & $1(0)$ & $115(15)$ & $9(4)$ & $1(1)$ & $0(1)$ & $7(3)$ & $15.5(3.25)$ \\
\hline
\end{tabular}

Footnote: Values are presented as median (Interquartile range).

According to Ayurveda, a healthy human body is supposed to have a relatively stable equilibrium (congenial homeostasis) of Dosha (psycho-biological rhythm - Vata, Pitta, Kapha), Dhatu (body tissues) and Mala (excreta) [4]. Imbalance in this equilibrium leads to disease, and the aim of the therapy is to restore this balance [4].

According to Ayurveda, the disease that closely resembles the symptoms associated with $\mathrm{OA}$ of knee is Janu Sandhigata Vata [1, 3, 4]. As per Ayurvedic concept, this disease is caused when the vitiated Vata gets localized in the knee joint (Janu Sandhi), and hence its treatment must involve procedures and Ayurvedic medicines that pacify the vitiated Vata at the site of knee joint $[1,3,4]$. Oleation and sudation therapies are recommended, as well as commonly used for the management of this disease with encouraging results $[1,3]$.

Janu Basti is a simple and effective oleation and sudation procedure of Ayurveda, which involves retaining warm medicated oil over the knee joint for sufficiently long duration [6]; as a result, the active principle of the oil is absorbed by the minute openings situated in the skin. As the oil used in Janu Basti is opposite to the nature of Vata; therefore, when it is absorbed by the skin and goes to the body tissues, it produces the desired therapeutic advantage. In this disease, the glue that binds the cells of the cartilage, is disrupted, leading to cartilage damage at the affected site; oil penetrates the cartilage, and helps in binding it together [18].

Ksheerbala oil was used for Janu Basti; this oil has been found useful in the management of diseases of different joints of the body, caused by the vitiated Vata $[4,5,13]$. The ingredients of Ksheerbala oil include Sida cordifolia Linn. (Bala) and cow's milk
(Ksheera), with Sesame oil as base. Sida cordifolia Linn. (Bala) has Vata pacifying and rejuvenating properties $[15,18]$; milk has properties like sweet taste, oily, cold nature, etc., which pacify Vata and Pitta [19]; and, Sesame oil pacifies Vata, as well as it has rejuvenating properties $[3,4,15,20]$. These properties of Ksheerbala oil, as well as the sudation induced by the warm oil, must have contributed to the observed therapeutic benefit in the present study.

In the treatment administered in this study, Janu Basti was followed by Nadi Sweda, i.e. the local application of medicated steam (generated from the decoction of Dashamoola) over the affected knee joint. The medicated steam creates sudation, which cleans the micro-channels, improves joint movement, and pacifies Vata and Kapha [18]. Sudation supports the activation of local metabolic process, causes an increase in the local blood flow, and hence leads to an increase in the absorption of oil through the skin [3,4]. Sudation produces sweating, and reduces stiffness and heaviness in the body $[18,21]$. Dashamoola is composed of roots of 10 medicinal plants, out of which 5 herbs have Vata and Kapha pacifying property, 4 herbs have Vata, Pitta and Kapha pacifying property, and 1 herb has Vata and Pitta pacifying property $[14,15]$. Since, this disease involves inflammation followed by degenerative changes, the Vata, Pitta and Kapha pacifying action of Dashamoola is especially useful in its treatment $[4,5,14]$. These properties of the medicated steam must have contributed to the observed therapeutic benefit in the present study.

\subsection{Effect of therapy on cardinal symptoms} Joint pain is the main symptom of osteoarthritis of knee, which was present in all the patients. In the 
present study, 50\% relief was observed in median value of joint pain (Table 2), which was statistically significant with $\mathrm{p}<0.01$. Vitiation of Vata was the primary reason for pain, and hence the best treatment was to pacify it. As discussed above, the properties of Ksheerbala oil are opposite to the properties of Vata, and hence it must have helped in subsiding the joint pain $[4,13]$.

The second prime symptom of osteoarthritis of knee is joint swelling, which was present in 7 (77.78\%) of the affected knees. There was an overall relief of $100 \%$ in the median value (Table 2), which was statistically significant with $\mathrm{p}<0.01$. The warmth applied by the Janu Basti procedure, and the medicinal properties of the oil are beneficial in reducing the swelling [4].

Next important symptom of osteoarthritis of knee is joint stiffness, which was present in all the patients. In this study, $100 \%$ relief was observed in the median value of joint stiffness, which was statistically significant with $\mathrm{p}<0.05$. When the disease is aggravated, the vitiated Vata might produce stiffness due to its dry and cool properties, leading to the restriction in movement [3]. Sudation helps in reducing stiffness and improving joint activity [3, 4].

Crepitus was present in all the patients, and an overall $50 \%$ relief was observed in the median values of the same, which was statistically significant with $\mathrm{p}<0.01$. Sudation provides relief in crepitus by regulating the aggravated Vata [3].

With regards to the knee joint flexion (ROM measured by a goniometer), $21.05 \%$ relief was observed in the median value of the same, which was statistically significant with $\mathrm{p}<0.01$. Movement of the knee joint was restricted because of the cool property of Vata, which causes stiffness [3]; sudation induced sweating, provided warmth and removed stiffness, causing better movement of the joint $[3$, 5].

On examining the walking time, $39.22 \%$ improvement was observed in the median value, which was statistically significant with $\mathrm{p}<0.05$. For the assessment of this parameter, patients were asked to walk a particular distance, and time taken for the same was noted, both before the starting of intervention and after the completion of intervention, as well as at the time of each follow-up. The knee is the chief weight bearing joint of the body, and it is the main joint that is affected in the patients of osteoarthritis of knee. Due to pain and stiffness in the joint, the patients had difficulty in walking. As the pain and stiffness reduced, difficulty in walking also reduced.

The WOMAC index (Modified - CRD Pune Version), which is suitable for Indian-Asian use [10,12], was used in this study to assess the pain, stiffness, and physical function in the patients. This questionnaire has 24 questions, which are divided into pain (1-5), stiffness (6-7) and physical function (8-24) sections; there are 3 extra optional questions under the physical function section $[10,12,22]$. The median value of WOMAC score before intervention was 48 , which reduced to 9 after completion of the study (Table 2); thus, there was $81.25 \%$ improvement in the median value of WOMAC score, which was statistically significant with $\mathrm{p}<0.01$. Since the therapeutic intervention reduced the pain and stiffness, and improved the physical function of the knee joint, hence the WOMAC score also reduced, illustrating the effectiveness of the therapeutic procedure.

Although the number of patients included in this pilot study was quite small, yet the level of relief experienced by all the patients is noteworthy. Also, the fact that the patients continued to experience more and more relief with time, even during the followup time when they were required to practice only some self-management techniques for the disease at their home, illustrates the promise that the present therapeutic procedure holds in providing the ability to the patients for long-term self-management of this disease, after short term initial therapeutic intervention under the supervision of a medical practitioner. This is definitely an encouraging outcome.

The major limitations of the present study include (i) small sample size; and, (ii) full time monitoring of the subjects could not be done, due to which there were obvious limitation in monitoring their following of dietary and other additional recommendations. Hence, with regards to the further research for this study, an in-depth quantitative study, with large sample size, full-time monitoring of subjects, and use of other state-of-the-art quantitative assessment tools, would definitely be worthwhile to establish the mode of operation of the administered therapeutic procedure in the light of modern scientific understanding. 


\section{Conclusion}

A pilot study has been presented here, which evaluates the efficacy of Janu Basti (with Ksheerbala oil) procedure of the traditional Indian system of medicine, Ayurveda, in the management of osteoarthritis of knee. Six patients completed the study, which involved treatment of nine knees. Significant improvement was observed in the median values of subjective parameters (joint pain, joint swelling, joint stiffness, and crepitus) and objective parameters (WOMAC index, ROM, walking time) analyzed during the study. Both during the initial therapeutic intervention of 21 days, as well as the follow-up time of 5 weeks when the patients had to do self-management of the disease at home, the patients continued to experience more and more relief with time. Thus, this study illustrates the significant promise that this therapeutic technique holds for the management of OA of knee.

\section{Compliance with ethical standards}

The study was approved by the 'Research Ethics Committee (REC) for research involving Human Participants' of Dev Sanskriti Vishwavidyalaya, Haridwar (REC-DSVV) (REC Ref no.: DSVV/PhD/ OS(AY)/0130108472, Dated: 11 May 2016).

\section{Acknowledgements}

Authors would like to acknowledge the subtle guidance of their spiritual guide, Revered Pandit Shriram Sharma Acharya (http://www.awgp.org/ about_us/patron_founder). The authors thank the faculty and staff of the Department of Ayurveda and Holistic Health at Dev Sanskriti Vishwavidyalaya, Haridwar for their support in conducting this study.

\section{Conflict of interest}

The authors declare that they have no conflict of interest.

\section{References}

[1] Rajoria K, Singh SK, Sharma RS, Sharma SN. Clinical study on laksha guggulu, snehana, swedana \& traction in osteoarthritis (knee joint). Ayu. 2010; 31(1):80-87.

[2] Long L, Soeken K, Ernst E. Herbal medicines for the treatment of osteoarthritis: a systematic review. Rheumatology. 2001; 40(7):779-793.

[3] Joshi A, Mehta CS, Dave AR, Shukla VD. Clinical effect of nirgundi patra pinda sweda and ashwagandhadi guggulu yoga in the management of sandhigata vata (osteoarthritis). Ayu. 2011; 32(2):207-212.

[4] Murthy KRS. Susruta samhita. Volume I, II, III. Varanasi, Uttar Pradesh, India: Chaukhambha Orientalia; 2008.

[5] Sharma PV. Charaka-samhita (text with English translation). Volume I, II. Varanasi, Uttar Pradesh, India: Chaukhambha Orientalia; 2008.
[6] Acharya GS. Panchakarma illustrated. Delhi: Chaukhamba Sanskrit Pratishthan; 2006.

[7] Chiluveri AC, Chiluveri SK, Patil RP. Ayurvedic management of osteoarthritis knee with grade IV severity and obesity (avaranajanya janu-sandhigatavata with sthoulya). Journal of Research in Ayurvedic Sciences. 2018; 2(4):240-246.

[8] Rakesh, Gopala KG, Sowmyashree UP, Umesh C. A controlled clinical study to evaluate the efficacy of janu basti and asthi shrinkhala in management of janusandhigata vata w.s.r to osteoarthritis. Journal of Ayurveda and Integrated Medical Sciences. 2020; 5(2):8-13.

[9] Chavan MS. A comparative study of janu basti with sahachar tail \& agnikarama with tamrashalaka in janu sandhigat vata. Thesis for the degree of Ayurveda Varidhi (Doctor of Philosophy (Ph.D.)) in Panchakarma. Pune, Maharashtra, India: Bharati Vidyapeeth; 2016. Available from: https:// shodhganga.inflibnet.ac.in/handle/10603/148802

[10] Chopra A, Saluja M, Tillu G, Venugopalan A, Sarmukaddam $\mathrm{S}$, et al. A randomized controlled exploratory evaluation of standardized ayurvedic formulations in symptomatic osteoarthritis knees: a government of India NMITLI project. Evidence-Based Complementary and Alternative Medicine. 2011; 2011:724291.

[11] Salaffi F, Leardini G, Canesi B, Mannoni A, Fioravanti A, et al. Reliability and validity of the Western Ontario and McMaster Universities (WOMAC) Osteoarthritis Index in Italian patients with osteoarthritis of the knee. OsteoArthritis and Cartilage. 2003; 11:551-560.

[12] Chopra A. Rheumatology: made in India (camps, COPCORD, HLA, ayurveda, HAQ, WOMAC and drug trials. Journal of Indian Rheumatology Association. 2004; 12:43-53.

[13] Grampurohit PL, Rao N, Harti SS. Effect of anuvasana basti with ksheerabala taila in sandhigata vata (Osteoarthritis). Ayu. 2014; 35(2):148-151.

[14] Pandey YK, Shalini, Sharma AK. Effect of Grīvā Vasti in management of Grīvā Asthi Sandhi Gata Vāta (Cervical Spondylosis). Ancient Science of Life. 2013; 33(1):71-75.

[15] Sastry JLN. Illustrated dravyaguna vijnana - volume II (study of the essential medicinal plants in Ayurveda). Varanasi, Uttar Pradesh, India: Chaukhambha Orientalia; 2017.

[16] Shastri KA. Bhaishajya ratnavali of shri govind das vidyotini Hindi commentary. Varanasi, Uttar Pradesh, India: Chaukhamba Prakashan; 2010.

[17] Sastri L. Yogaratnakara - with 'vidyotini' Hindi commentary (Hindi). (Editor) Sastri B. Varanasi, Uttar Pradesh, India: Chaukhambha Prakashan; 2018.

[18] Shah MR, Mehta CR, Shukla VD, Dave AR, Bhatt NN. A clinical study of matra vasti and an ayurvedic indigenous compound drug in the management of sandhigatavata (Osteoarthritis). Ayu. 2010; 31(2):210-217.

[19] Pokharel S, Sharma AK. Evaluation of insomrid tablet and shirodhara in the management of anidra (insomnia). Ayu. 2010; 31(1):40-47.

[20] Kundu C, Shukla VD, Santwani MA, Bhatt NN. The role of psychic factors in pathogenesis of essential hypertension and its management by shirodhara and sarpagandha vati. Ayu. 2010; 31(4):436-441.

[21] Akhtar B, Mahto RR, Dave AR, Shukla VD. Clinical study on sandhigata vata w.s.r. to osteoarthritis and its management by panchatikta ghrita guggulu. Ayu. 2010; 31(1):53-57.

[22] Mangal A, Shubhasree MN, Devi P, Jadhav AD, Prasad SA, Kumar K, Otta S, Dhiman KS. Clinical evaluation of vatari guggulu, maharasnadi kwatha and narayan taila in the management of osteoarthritis knee. Journal of Ayurveda and Integrative Medicine. 2017; 8:200-204. 